\title{
Effect of arginase II on L-arginine depletion and cell growth in murine cell lines of renal cell carcinoma
}

\author{
David J Tate Jr ${ }^{1}$, Derek J Vonderhaar ${ }^{1}$, Yupanqui A Caldas ${ }^{2}$, Toye Metoyer ${ }^{3}$, \\ John R Patterson IV ${ }^{1}$, Diego H Aviles ${ }^{4}$ and Arnold H Zea*1,5
}

Address: ${ }^{1}$ Stanley S. Scott Cancer Center, LSUHSC, New Orleans, USA, ${ }^{2}$ Division of Renal Diseases and Hypertension, UCDHSC, Denver, Colorado, USA, ${ }^{3}$ Morehouse School of Medicine, Atlanta GA, USA, ${ }^{4}$ Division of Pediatric Nephrology, Children's Hospital, New Orleans, LA, USA and ${ }^{5}$ Microbiology Immunology and Parasitology, LSUHSC, New Orleans, LA, USA

Email: David J Tate - dtate1@Isuhsc.edu; Derek J Vonderhaar - dvonde@lsuhsc.edu; Yupanqui A Caldas - yupanqui.caldas@uchsc.edu; Toye Metoyer - tmetoyer@msm.edu; John R Patterson - jpatt3@Isuhsc.edu; Diego H Aviles - davile@lsuhsc.edu;

Arnold H Zea* - azea@lsuhsc.edu

* Corresponding author

Published: 25 September 2008

Journal of Hematology \& Oncology 2008, I:14 doi:10.1 186/1756-8722-1-14
Received: 29 July 2008

Accepted: 25 September 2008

This article is available from: http://www.jhoonline.org/content/l/I//4

(c) 2008 Tate et al; licensee BioMed Central Ltd.

This is an Open Access article distributed under the terms of the Creative Commons Attribution License (http://creativecommons.org/licenses/by/2.0), which permits unrestricted use, distribution, and reproduction in any medium, provided the original work is properly cited.

\begin{abstract}
Background: L-arginine is the common substrate for the two isoforms of arginase. Arginase I, highly expressed in the liver and arginase II mainly expressed in the kidney. Arginase I-producing myeloid derived suppressor cells have been shown to inhibit T-cell function by the depletion of L-arginine. On the other hand, arginase II has been detected in patients with cancer and is thought to metabolize L-arginine to L-ornithine needed to sustain rapid tumor growth; however its role in L-arginine depletion is unclear. Thus, in tumor biology, L-arginine metabolism may play a dual role in tumor growth and in the induction of $\mathrm{T}$ cell dysfunction. Therefore, we studied in murine renal cell carcinoma (RCC) cell lines, the effect of arginase II on tumor cell proliferation and L-arginine depletion. The effect of arginase inhibitors on cell proliferation was also tested.

Methods: Three murine renal cell carcinoma (mRCC) cell lines were tested for the presence of arginase. nor$\mathrm{NOHA}$, an arginase inhibitor was used to substantiate the effect of arginase on cell growth and L-arginine depletion. Amino acid levels were tested by HPLC.

Results: Our results show that $\mathrm{mRCC}$ cell lines express only arginase II and were able to deplete L-arginine from the medium. Cell growth was independent of the amount of arginase activity expressed by the cells. nor-NOHA significantly $(P=0.0 \mathrm{I})$ reduced arginase II activity and suppressed cell growth in cells exhibiting high arginase activity.

The depletion of $\mathrm{L}$-arginine by $\mathrm{mRCC}$ induced the decrease expression of $\mathrm{CD} 3 \zeta$ a key element for $\mathrm{T}$-cell function.

Conclusion: The results of this study show for the first time that arginase II produced by RCC cell lines depletes L-arginine resulting in decreased expression of $\mathrm{CD} 3 \zeta$. These results indicate that RCC cell lines expressing arginase II can modulate the L-arginine metabolic pathway to regulate both cell growth and T-cell function. Blocking arginase may lead to a decrease in RCC cell growth and aid in restoring immune function by increasing L-arginine availability for T-cell use. Understanding the interplay between arginase II and its interaction with the immune system may provide future therapeutic benefits to treat patients with RCC.
\end{abstract}




\section{Background}

L-arginine is a basic amino acid that plays a central role in multiple systems including the immune system [1-3]. Two independent enzymatic pathways, arginase and inducible nitric oxide synthase (iNOS), regulate L-arginine availability. L-arginine is metabolized to L-ornithine and urea by arginase, which is important in the urea cycle and in the biochemical pathways essential for cell proliferation [4,5]. Arginase has two isoforms: arginase I, a cytosolic enzyme found predominantly in hepatocytes, erythrocytes, and granulocytes [6-8] and arginase II, found in the mitochondria of many different tissues, including kidney, brain, and prostate $[6,9,10]$. Arginase I, is primarily involved in the detoxification of ammonia and urea synthesis, whereas arginase II is involved in the synthesis of L-ornithine, L-proline, and L-glutamate [11].

Several studies have shown that decreased plasma Larginine levels and nitric oxide (NO) metabolites induced by trauma are associated with an increase in arginase I expression in mononuclear immune cells $[12,13]$, suggesting that L-arginine may have an effect on metabolic processing in the immune system. In patients with renal cell carcinoma (RCC), we have demonstrated that arginase I-producing myeloid suppressor cells depletes plasma L-arginine levels that decreases the expression of T-cell CD3 $\zeta$ chain [14]. Arginase II on the other hand, is constitutively expressed in normal kidney [15] and its activity shown to be increased in breast, colon, and prostate cancer [16-18]. This activity may sustain the high demand of polyamines necessary for tumor growth. Even though, the depletion of $\mathrm{L}$-arginine has been exclusively attributed to arginase I [19-21], the potential role of arginase II in Larginine depletion has not been taken into detailed consideration. Likewise, the role of arginase II in tumor growth and in the induction of T-cell dysfunction has not been determined.

In this study we demonstrate for the first time that only arginase II is produced by murine renal cell carcinoma (mRCC) cell lines and that high enzyme levels, specifically depletes extra cellular L-arginine. This amino acid deprivation induces the downregulation of $\mathrm{CD} 3 \zeta$ expression in co-cultured Jurkat T-cells. Arginase inhibitors significantly suppressed cell growth in cell lines presenting high arginase II activity.

\section{Methods}

\section{Tissue culture medium}

Complete tissue culture medium consisted of RPMI-1640 containing 1,140 $\mu \mathrm{M} \mathrm{L}$-arginine and supplemented with $10 \%$ fetal calf serum (Hyclone, Logan, UT), $25 \mathrm{mM}$ HEPES, $4 \mathrm{mM}$ L-glutamine, and 100 units/mL penicillin/ streptomycin, $1 \mathrm{mM}$ non-essential amino acids, and 1
$\mathrm{mM}$ sodium pyruvate. All other reagents were purchased from Lonza Walkersville Inc., Walkersville, MD.

\section{Cell culture}

For this study we used mRCC cell lines SIRCC-1.2 (CL-2) and SIRCC 1.19 (CL-19), both of which are sub-clones derived from a streptozotocin-induced kidney tumor [22] and Renca. All of the cell lines were kindly provided by Dr. Robert H. Wiltrout (NCI). Cells were cultured at $37^{\circ} \mathrm{C}$ in complete media and subcultured every 3 days. Experiments were prepared by plating 300,000 cells in six-well plates and allowed to attach for 24 hours. Media was changed (Time 0) to perform all of the experiments. The cells were harvested at 24, 48, and 72 hours using 0.5\% Trypsin/EDTA (Sigma, St. Louis, MO) and lysed with a Triton-based buffer [23] to obtain cytoplasmic extracts to test immediately for arginase activity. Protein concentration was determined by the BCA (bicinchoninic acid) protein assay kit (Pierce Biotechnology Inc., Rockford, IL). Lysates were stored at $-70^{\circ} \mathrm{C}$ until used for Western blots.

\section{Arginase activity}

Freshly prepared cytoplasmic extracts from cultured mRCC cells were tested for arginase activity by the conversion of L-arginine to L-ornithine (nanomoles $/ 10^{6} \mathrm{cells}$ / hr), as described elsewhere [24].

\section{Western blot}

Twenty-five micrograms of cytoplasmic extract were electrophoresed in $14 \%$ Tris-glycine gels (Invitrogen, Carlsbad, CA) and transferred to polyvinylidiene difluoride (PVDF) membranes (Invitrogen). Immunoblotting were performed with antibodies for arginase I or arginase II (1:200, Santa Cruz Biotech, Santa Cruz, CA). Detection was achieved by horseradish peroxidase-conjugated antibodies (1:3000, Santa Cruz) and an enhanced chemiluminescent kit (ECL, GE Healthcare, Piscataway, NJ). Arginase protein levels were visualized on X-OMAT AR films (Kodak, Rochester, NY).

\section{Reverse transcriptase polymerase chain reaction (RT-PCR)} Total RNA from $1 \times 10^{6}$ cells were extracted using TRIzol (Invitrogen), treated with DNase I (Invitrogen), and reverse transcribed using Superscript II (Invitrogen). PCR amplification was done using primers for mouse arginase I, arginase II, and $\beta$-actin as follow: Arginase I forward 5'CAG AAG AAT GGA AGA GTC AG-3', reverse 5'-CAG ATA TGC AGG GAG TCA CC-3', Arginase II forward 5'-TGA TTG GCA AAA GGC AGA GG-3', reverse 5'-CTA GGA GTA GGA AGG TGG TC-3', and $\beta$-actin forward 5 '-CCA GAG CAA GAG AGG TAT CC-3', reverse 5'-CTG TGG TGG TGA AGC TGT AG-3'. The expected sizes of amplified fragments were arginase I, $250 \mathrm{bp}$; arginase II, $310 \mathrm{bp}$; and $\beta$ actin, 436 bp. PCR products were visualized in ethidium bromide agarose gels. 


\section{Amino acid detection}

High performance liquid chromatography (HPLC) was conducted on deproteinized supernatants labeled with $O$ phtaldialdehyde (OPA). Analytes were eluted with 100 mM sodium acetate buffer, $\mathrm{pH} 5.0$, with a linear gradient consisting of methanol (80\%) and acetonitrile $(80 \%)$. The analytes in the sample were calculated on the basis of standard curves of known amounts.

\section{Proliferation assays}

Cells $\left(1 \times 10^{4} /\right.$ well $\left./ 1 \mathrm{~mL}\right)$ were plated in 24 -well plates and allowed to adhere for 24 hours. The cells were treated with different concentrations of $\mathrm{N}^{\omega}$-Hydroxy-nor-Larginine (nor-NOHA), $0.5 \mathrm{mM}, 1 \mathrm{mM}$, and $2 \mathrm{mM}$ to determine the optimal conditions to suppress cell growth, or cultured without the inhibitor to be used as controls. The cultures were pulsed once with $\left[{ }^{3} \mathrm{H}\right]$-thymidine $(1.0$ $\mu \mathrm{Ci}$, Perkin Elmer Life Sciences, Boston, MA) and tested for $\left[{ }^{3} \mathrm{H}\right]$ incorporation at 24, 48, and 72 hours using a TOPCOUNT Microplate Scintillation Counter (Packard, Meridien, CT). Cell viability was checked by trypan blue exclusion at each time point. Each condition was tested in triplicate.

\section{Expression of $\mathrm{CD} 3$ ל by co-cultured Jurkat T-cells}

To determine the effect of L-arginine deprivation on the expression of CD3 $\zeta$, mRCC cell lines $(600,000$ cells/well) were cultured in six-well plates with $5 \mathrm{~mL}$ of complete media for 24 hours. $5 \times 10^{5}$ Jurkat T-cells (ATCC, Manassas, VA) were then added to the upper chamber of a transwell system (Falcon-BD, San Jose, CA) and co-cultured for 24,48 , and 72 hours. CD3 $\zeta$ expression was determined by flow cytometry as described elsewhere [25]. Jurkat cells cultured in complete media were used as controls. Larginine levels were determined in the supernatants by HPLC.

\section{Statistical analysis}

Statistical analysis was calculated by Student's $t$-test using the Graph Pad Prism 3.0 statistical program (GraphPad Software Inc., San Diego, CA). $P<0.05$ was taken to indicate statistical significance.

\section{Results \\ Arginase expression in $\mathrm{mRCC}$ cell lines}

First, we investigated the enzymatic activity of arginase in the mRCC cell lines CL-2, CL-19, and Renca. CL-19 cell line had the highest arginase activity, which was 3.0-fold greater than the Renca and 9.8-fold greater than the CL-2 cell line (Figure 1A). Using specific antibodies for arginase I and arginase II, we found that the cell lines only expressed detectable levels of arginase II, and not arginase I (Figure 1B). By RT-PCR, we observed arginase II gene expression in all 3 of the mRCC cell lines, but not arginase I gene expression (Figure 1C). Arginase II mRNA expres- sion was greatest in CL-19 compared to Renca and CL-2 cell lines. The data show a direct association amongst arginase II mRNA expression, protein expression, and enzymatic activity.

\section{Arginase II produced by the CL- 19 cell line depletes extra cellular L-arginine}

The effect of arginase II on L-arginine, L-ornithine, and Lglutamine content in the conditioned culture medium was assessed by HPLC. The CL-19 cell line, which expressed high levels of arginase II, depleted the media Larginine concentration by about $50 \%$ at 24 hours $(P=$ 0.005 , Figure $2 A)$ and about $90 \%$ at 48 and 72 hours $(P<$ 0.001 ) when compared to media controls. L-arginine levels remained unchanged in CL-2 and Renca cultures throughout the experimental time points. Concomitantly, there was a significant increase in L-ornithine production by CL-19 after 48 and 72 hours $(P=0.001$ and $P<0.0001)$ compared to CL-2 and Renca cell lines in which the levels did not change significantly at any time point (Figure 2B). All cell lines also depleted the culture supernatants of Lglutamine at the same rate during the first 24 hours. However, at 72 hours, the depletion of L-glutamine was significantly higher in CL-2 and Renca $(P=0.001$ and $P=$ 0.016) than in CL-19 (Figure 2C).

\section{Role of arginase II and effect of nor-NOHA on $\mathrm{mRCC}$ cell proliferation}

We assessed whether arginase II could play a role in the proliferation of the three different mRCC cell lines. The cell lines were cultured for 24 hours and the media replaced with $0.5,1$ and $2 \mathrm{mM}$ of nor-NOHA, pulsed once with $\left[{ }^{3} \mathrm{H}\right]$-thymidine and tested for $\left[{ }^{3} \mathrm{H}\right]$ incorporation after 24, 48, and 72 hours in culture. At 72 hours in culture a concentration of $2 \mathrm{mM}$ nor-NOHA was able to significantly suppress cell growth in the high arginase producer CL-19 cell line. No significant effect on cell growth suppression was observed with the lower concentrations of nor-NOHA (data not shown). Therefore, we used $2 \mathrm{mM}$ nor-NOHA for the rest of the experiments.

When the 3 cell lines were cultured in presence of $2 \mathrm{mM}$ nor-NOHA, they incorporated $\left[{ }^{3} \mathrm{H}\right]$-thymidine at the same rate during the first 48 hours. However at 72 hours, significant differences in cell proliferation among the lines were apparent. CL-2 proliferation was significantly lower $(P=0.003)$ compared to CL-19, which presented the highest arginase activity. Interestingly, the Renca cell line, which had intermediate arginase activity, had the highest proliferation rate compared to the CL-19 $(P=$ $0.01)$ and CL-2 $(P=0.003)$ cell lines (Figure $3 \mathrm{~A})$. The higher L-glutamine consumption observed in Renca cells (Figure 3C) suggested that this line may utilize a different pathway for its cellular growth, bypassing arginase for the production of L-ornithine. 

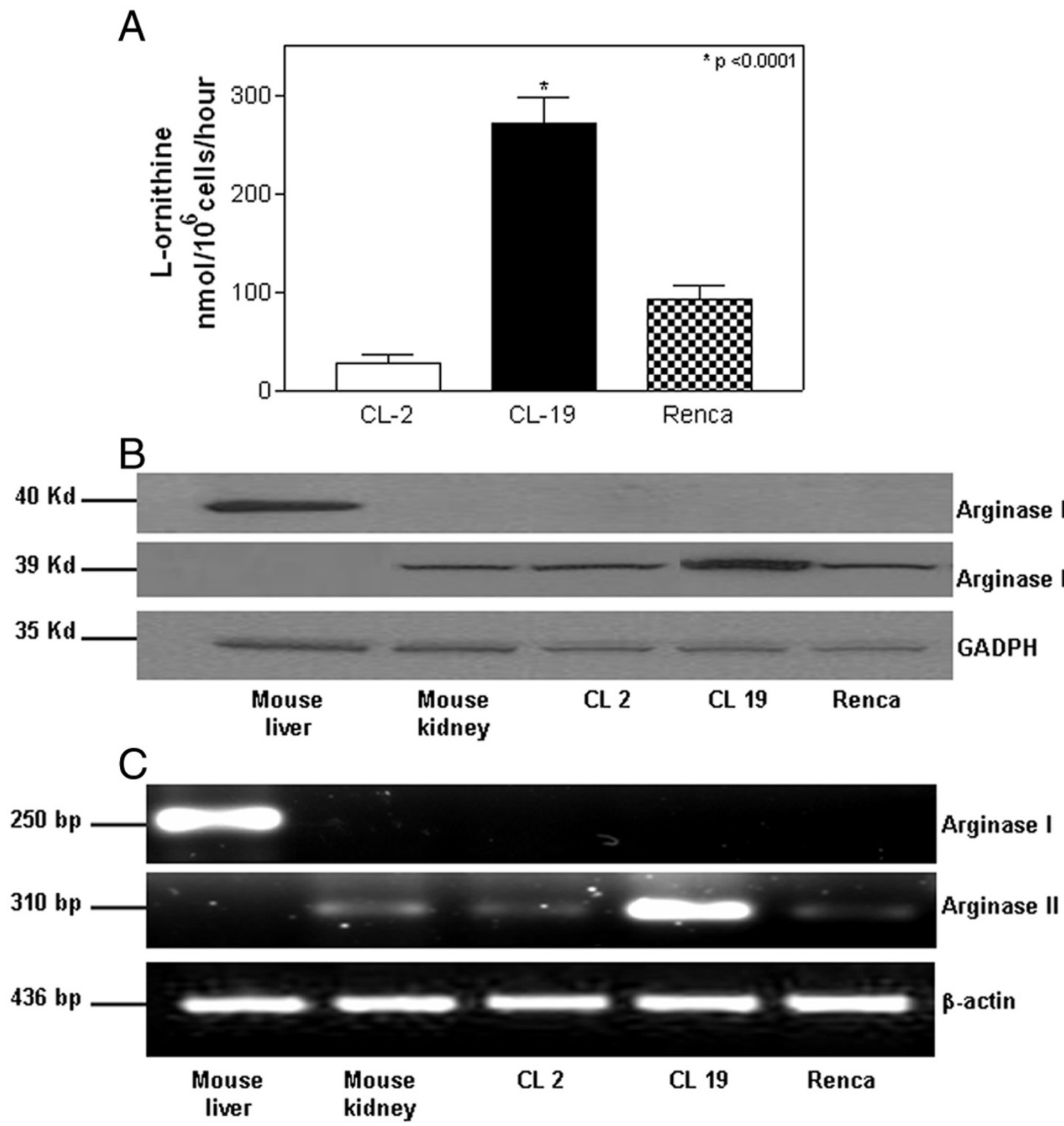

Figure I

Arginase II expression in mRCC cell lines. (A) After 48 hours in culture, CL- 19 cells presented significantly more arginase activity $(* P<0.000 I)$ than did either $C L-2$ or Renca cells. Similar results were found after 72 hours in culture. (B) Twenty five micrograms of protein were tested for arginase I and arginase II expression by Western blot analysis. Normal mouse liver and kidney were used as positive controls for arginase I and arginase II respectively, whereas GAPDH was used as house keeping protein. (C) Total RNA from CL-2, CL-19 and Renca cells were obtained by TRlzol extraction and I $\mu g$ of RNA was tested for arginase I, arginase II, and $\beta$-actin by RT-PCR. DNA fragment sizes generated by RT-PCR: arginase I, 250 bp; arginase II, 3 I 0 bp; and $\beta$-actin, $436 \mathrm{bp}$. These data are from a single experiment that is representative of five separate experiments. 

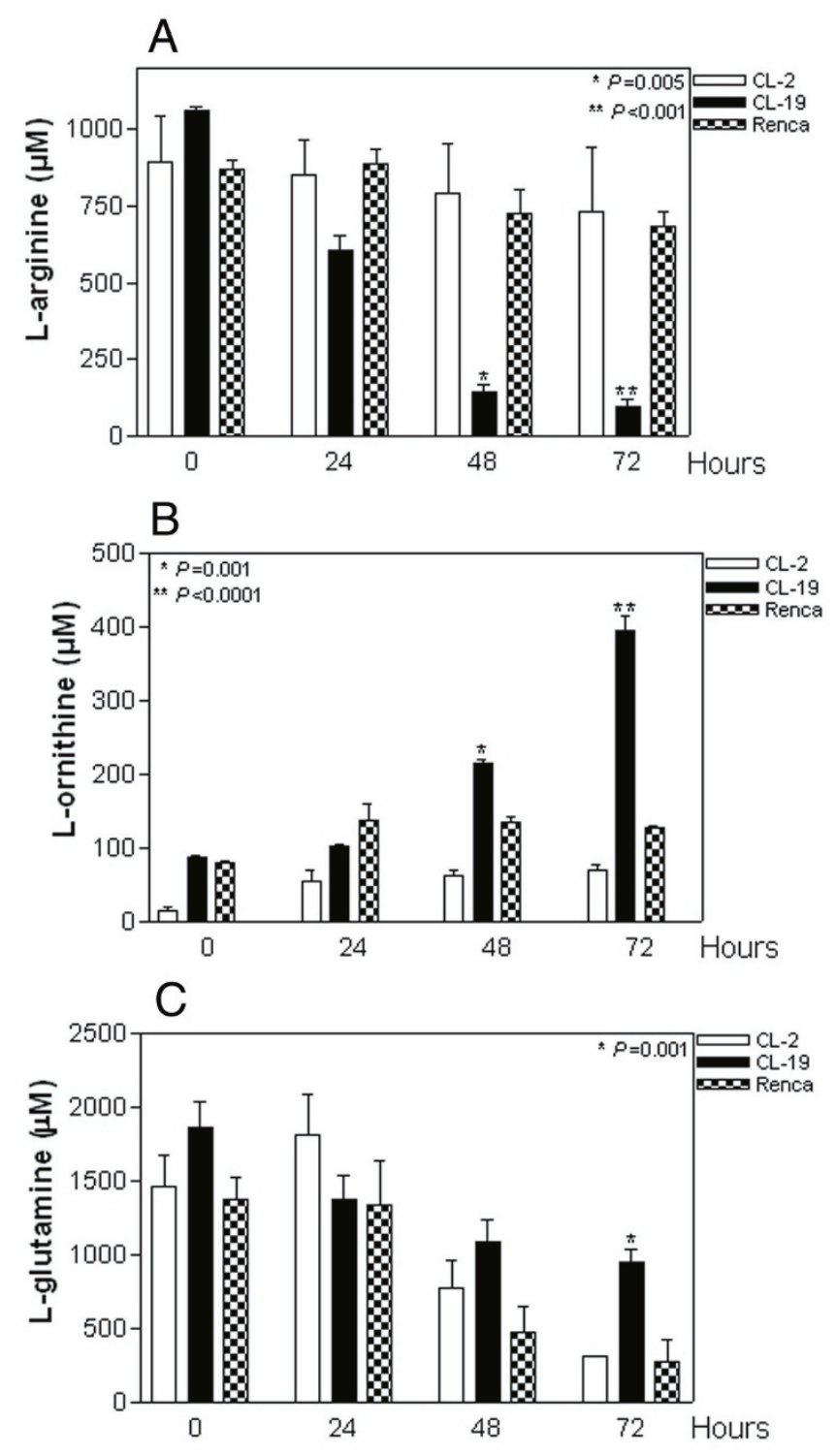

Figure 2

L-arginine, L-ornithine and L-glutamine levels. Tissue culture supernatants from CL-2, CL-19, and Renca cells were collected at 24,48 , and 72 hours. They were analyzed by HPLC after deproteinization with methanol and derivatization with OPA for $(A)$ L-arginine and $(B)$ L-ornithine and $(C)$ L-glutamine. Standards of L-arginine, L-ornithine and Lglutamine in methanol were run with each experiment. Results are expressed as means \pm SE of duplicate determinations from four independent experiments. ( $* P=0.005$. ** $P$ $<0.000$ I significant differences for CL- 19 compared to the other cell lines).

We then tested the effect of the arginase inhibition by norNOHA ( $2 \mathrm{mM}$ ) on cell proliferation at 24, 48, and 72 hours. Growth of CL-19, which had the highest level of arginase II activity, was significantly inhibited $(P=0.017$,
Figure 3B). In contrast, nor-NOHA had no significant effects on the growth rates of the low arginase producer cell lines CL-2 $(P=0.14)$ and Renca $(P=0.07)$. Cell viability of the cells was $>95 \%$ at the different points and conditions of the experiments.

\section{nor-NOHA blocks arginase activity and L-arginine consumption in CL-19 cell line}

Since nor-NOHA significantly inhibited cell proliferation of CL-19, we wanted to test the effect of this inhibitor on arginase activity and L-ornithine production. Arginase activity increased in this cell line over the time of the experiments. When $2 \mathrm{mM}$ of nor-NOHA was added to the cultures, significant reduction in arginase activity occurred at 48 and 72 hours $(P=0.002$ and $P=0.001$ respectively) (Figure 4A). Importantly, independent of the amount of arginase produced by this cell line, the effect of arginase inhibition by nor-NOHA was similar at all time points tested. The inhibition of arginase activity in CL-19 by norNOHA significantly blocked $(P=0.0001)$ the depletion of L-arginine as well as the accumulation of L-ornithine $(P<$ 0.0001 ) after 48 hours compared to CL-19 cultures without the inhibitor (Figure 4B). We did not observe significant changes in arginase inhibition, L-arginine depletion and L-ornithine production when nor-NOHA was added to cultures with CL-2 and Renca cells (data not shown).

\section{L-arginine depletion by arginase II induces CD3 $\zeta$ downregulation in Jurkat T-cells}

Jurkat T-cells rapidly lose CD3 $\zeta$ in absence of L-arginine. Therefore, we tested if L-arginine depletion by mRCC arginase II had any effect on CD3 $\zeta$ expression in trans-wells co-cultured Jurkat T-cells. At 24 hours in co-culture with any of the mRCC cell lines, Jurkat T-cells did not show any significant reduction on $\mathrm{CD} 3 \zeta$ expression. However, after 48 hours Jurkat T-cells co-cultured with CL-19 had a dramatic decrease in the expression of $\mathrm{CD} 3 \zeta$ as compared to Jurkat controls (MFI: 16.9 and 48.5 respectively, Figure 5). The decreased expression of CD3 $\zeta$ in Jurkat T-cells paralleled the significant depletion of L-arginine $(P=0.03)$ in the co-cultured CL-19 compared to the Jurkat control (Figure 5 lower panel). In contrast, the expression of $\mathrm{CD} 3 \zeta$ in Jurkat T-cells co-cultured with CL- 2 or Renca was similar to that expressed in the Jurkat control, where the levels of L-arginine remained unchanged (Figure 5).

\section{Discussion}

Our major objective was to assess whether arginase II was able to deplete L-arginine from the tissue culture supernatants of murine renal cell carcinoma cell lines and determine their effect on cell proliferation. In adult mammals, the majority of endogenous L-arginine is synthesized from citrulline in the kidney and released to systemic circulation where it is catabolized by arginase I or arginase II $[4,11]$. Therefore, the study of the L-arginine metabolic 

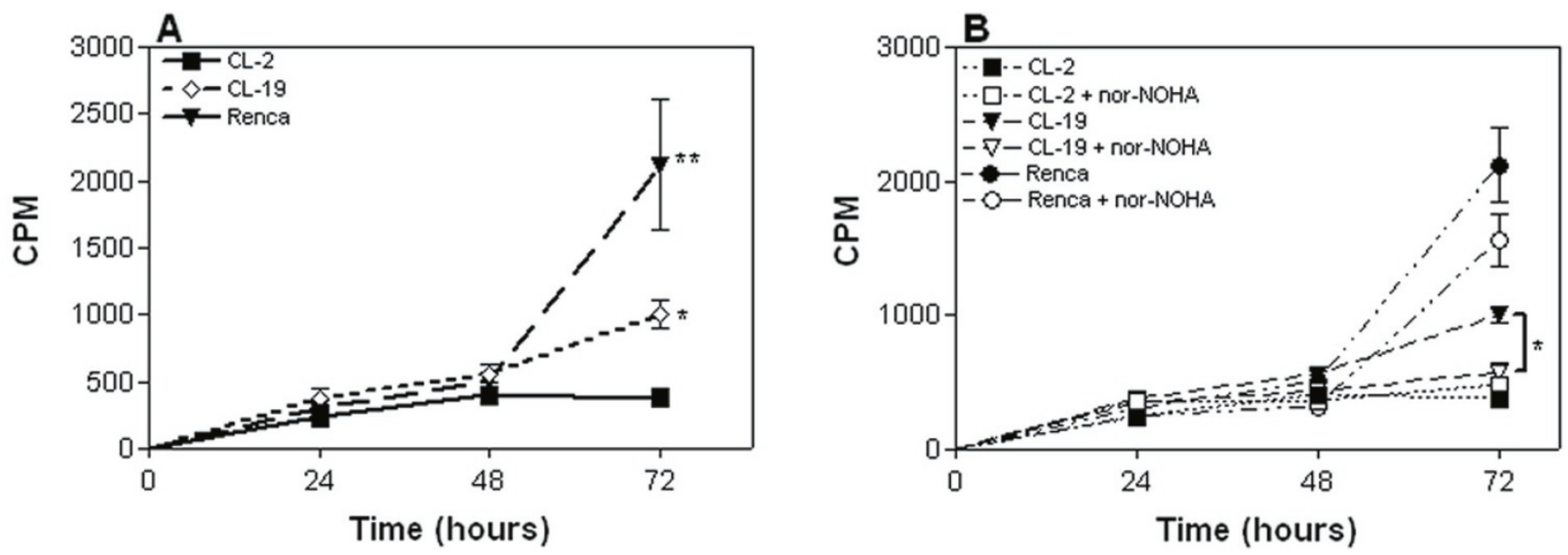

Figure 3

Effect of arginase inhibitor nor-NOHA on cell proliferation. (A) Proliferation of CL-2, CL- 19 and Renca cells was assessed by $\left[{ }^{3} \mathrm{H}\right]$-thymidine incorporation at 24,48 , and 72 hours in culture. At 72 hours, the growth rates for $\mathrm{CL}-19$ and Renca cells were significantly greater than CL-2 (*P=0.009 and $* * P=0.003$ respectively). (B) nor-NOHA $(2 \mathrm{mM})$ and $\left[{ }^{3} \mathrm{H}\right]-$ thymidine were added at the same time and cell proliferation was determined at 24,48 , and 72 hrs. Cultured cells without the inhibitor were used as controls. Only CL-19 proliferation was significantly inhibited $(* P=0.010)$ compared to the untreated control cells. Results are expressed as CPM means \pm SE of triplicate determinations from five independent experiments.

pathway in mRCC cell lines provide us with a good model to better understand the biology of renal carcinoma.

Western blot and RT-PCR analyses confirmed that arginase activity from mRCC cell lines was attributable solely to arginase II and not to arginase I. This is an important finding, since most studies have demonstrated that only arginase I produced by tumor cells, macrophages, smooth muscle and endothelial cells [26-29] is capable of depleting L-arginine which results in the induction of T-cell dysfunction [19,30]. The role of arginase II on L-arginine metabolism in disease and cancer has been quite underestimated, especially taking into account its wide tissue distribution and its role in polyamine production. Previous studies have shown that the expression of either arginase I or arginase II plays a key role in polyamine synthesis and cell proliferation [31]. Although the three cell lines used in this study were all derived from kidney tumors, they had very different arginase II activities. CL-2 and CL-19, both derived from renal tumors induced by streptozotocin, had low and high arginase II activities, respectively. The Renca cell line, derived from a spontaneous renal tumor had intermediate activity. These three lines provide us with an ideal model to study the biology of RCC with regard to L-arginine consumption, L-ornithine production, and cell proliferation. We demonstrate for the first time that arginase II produced by the high arginase RCC cell line CL-19 dramatically depletes L-arginine from the tissue culture supernatants at 48 hours with a concomitant increase in L-ornithine production.
In contrast, the cell lines CL-2 and Renca, both of which expressed low levels of arginase II compared to CL-19 did not deplete L-arginine significantly; nor did they increase the levels of L-ornithine sufficiently to promote growth. Instead, we observed that CL-2 and Renca cells utilize Lglutamine at higher rates than CL-19, suggesting that this could be a possible mechanism used by these cells to convert L-glutamine to glutamate, bypassing arginase for the production of L-ornithine as described previously in murine macrophages and human monocytes [32]. It is likely that CL-2 and Renca cells do not need arginase to make L-ornithine because they utilize L-glutamine to produce the necessary amount of L-ornithine needed for their cell growth. This observation indicates that arginase II is important for CL-19 growth but not for CL-2 and Renca cells due to the positive effect of nor-NOHA in suppressing cell growth in CL-19. We used nor-NOHA in our experiments because it has been demonstrated that norNOHA is a potent and selective inhibitor of arginase [33] in contrast to NOHA which is a key intermediate product in the biosynthesis of nitric oxide by L-arginine. We were expecting to have a greater arginase inhibition by norNOHA in our cultures similar to those observed when NOHA was used to inhibit cell proliferation in cell lines from breast, colon, prostate and endothelial cells as previously reported $[16,17,34,35]$. This may be due to the fact that these cell lines can use L-arginine to synthesize NOHA from arginase, then increasing its inhibitory effect. In contrast, it is also possible the growth of renal cell carcinoma cells is arginase II independent resulting in the low inhibitory effect of nor-NOHA. 

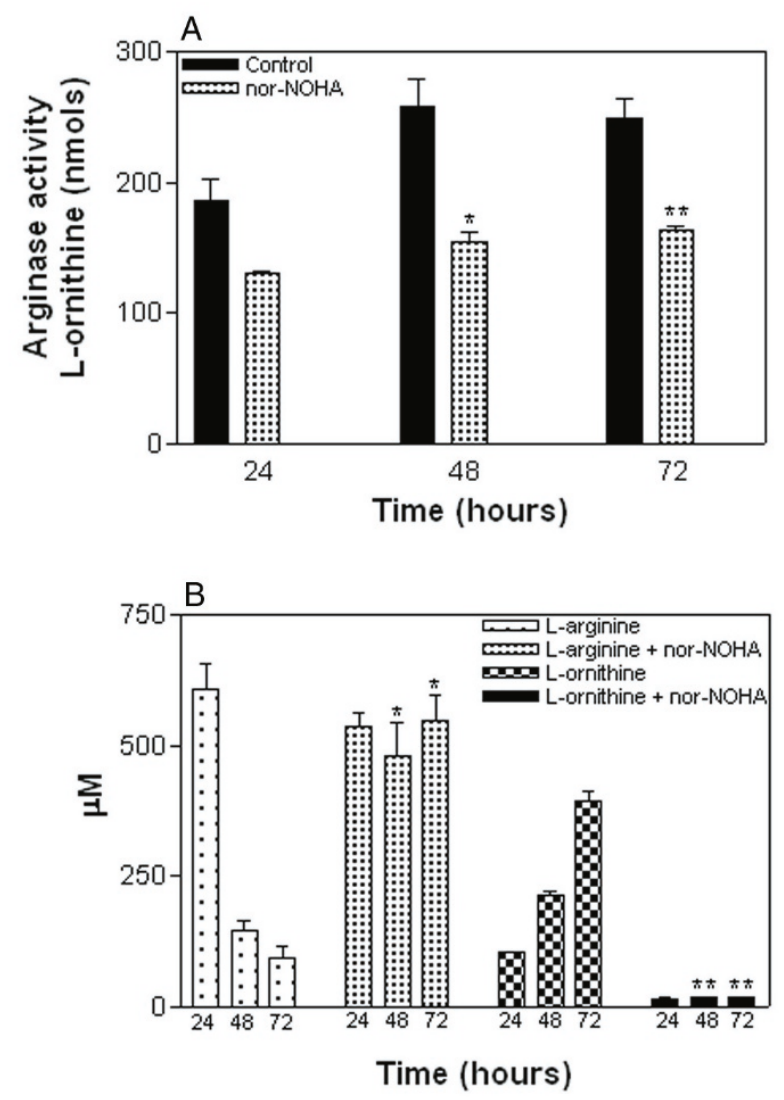

\section{Figure 4}

Effect of nor-NOHA on arginase activity and amino acid levels. (A) Significant arginase inhibition was observed in cell lysates of CL- 19 cultures treated with nor-NOHA (2 $\mathrm{mM})$ after $48(* P=0.002)$ and 72 hours $(* * P=0.001)$ as compared to untreated cells. (B) Effect of nor-NOHA in inhibiting both $L$-arginine $(\mu \mathrm{M})$ depletion $(* P=0.00 \mathrm{I})$ and $\mathrm{L}$ ornithine $(\mu \mathrm{M})$ production $(* * P<0.000 \mathrm{I})$ in the supernatants of CL- 19 cultures, as compared to CL- 19 untreated cultures. Results are expressed as means \pm SE of duplicate determinations from four independent experiments.

At 48 hours in culture, CL-19 cells significantly depleted L-arginine from the culture supernatant; however, these cells continued growing at the same rate up to 120 hours in the absence of the amino acid (data not shown). Larginine deprivation should promote the death of CL-19 cells, as reported previously to occur in other cancer cells lines $[36,37]$, indicating that these cells are more adept at circumventing L-arginine deficiency by increasing the recycling efficiency from L-ornithine to citrulline to convert L-arginine fast enough to sustain relatively normal tumor cell growth rate as previously shown [38]. Since RCC cells have a strong dependence for L-arginine [39], our laboratory is currently studying whether or not these cells are utilizing L-glutamine or citrulline as the source for L-arginine synthesis.

L-arginine is a non-essential amino acid that plays a central role in several biological systems including the immune response. Paradoxically, L-arginine deprivation can cause tumor cell death as well as T-cell dysfunction. The loss of $\mathrm{CD} 3 \zeta$ is the only arginase-triggered mechanism described so far that has proven to have direct relevance to T-cell function $[40,41]$. It has been previously shown that Jurkat T-cells cultured in medium lacking Larginine showed decreased expression of $\mathrm{CD} 3 \zeta$ and decreased cell proliferation [42]. Similar results were obtained when stimulated normal human T-cell lymphocytes were cultured in the absence of L-arginine [25]. In the current experiments, we found that after 48 hours in culture, depletion of L-arginine by CL-19 arginase II activity caused the decreased expression of $\mathrm{CD} 3 \zeta$ in cocultured Jurkat T-cells. Therefore, L-arginine availability can regulate the expression of $\mathrm{CD} 3 \zeta$, an essential component in T-lymphocyte signal transduction and function. Larginine levels in the serum of normal individuals ranges from $115 \mu \mathrm{M}$ to $210 \mu \mathrm{M}$ [4]. Our data show that at 48 hours, the levels of L-arginine in the trans-well tissue culture supernatant was $100 \mu \mathrm{M}$, a concentration sufficient to induce a decrease in $\mathrm{CD} 3 \zeta$ expression.

Most tumor cells have a great demand for amino acids to support rapid proliferation and L-arginine is the first amino acid depleted faster than other nutrients by normal cell metabolism. Therefore, L-arginine could be a reasonable target of deprivation strategy for the type of tumors with a low recycling efficiency. Taken collectively, these findings, demonstrate that the availability of L-arginine and L-ornithine could be the limiting factor to control cell proliferation. We believe that treating RCC cells downstream from the L-arginine metabolic pathway by blocking polyamine production will have a major impact in suppressing tumor growth. This is supported by the use of DL- $\alpha$-difluoromethylornithine, which completely blocks the proliferation of these cell lines independent of the presence of L-arginine, L-ornithine and arginase in addition to the promising anti-tumor effect in human tumors [43-45].

Renal cell carcinoma is a malignancy with poor prognosis due to its strong resistance to conventional cancer treatments and frequent metastases. With the standard immunotherapeutic treatment of IL-2 and IFNa for RCC, only $10-20 \%$ of the patients respond [46]. This lack of response may be caused by the markedly impaired T-cell function associated with a decreased expression of the $\mathrm{CD} 3 \zeta$ receptor. Therefore, it is still desirable to find better approaches to treat RCC. Modulating the L-arginine metabolic pathway by breaking down this amino acid 

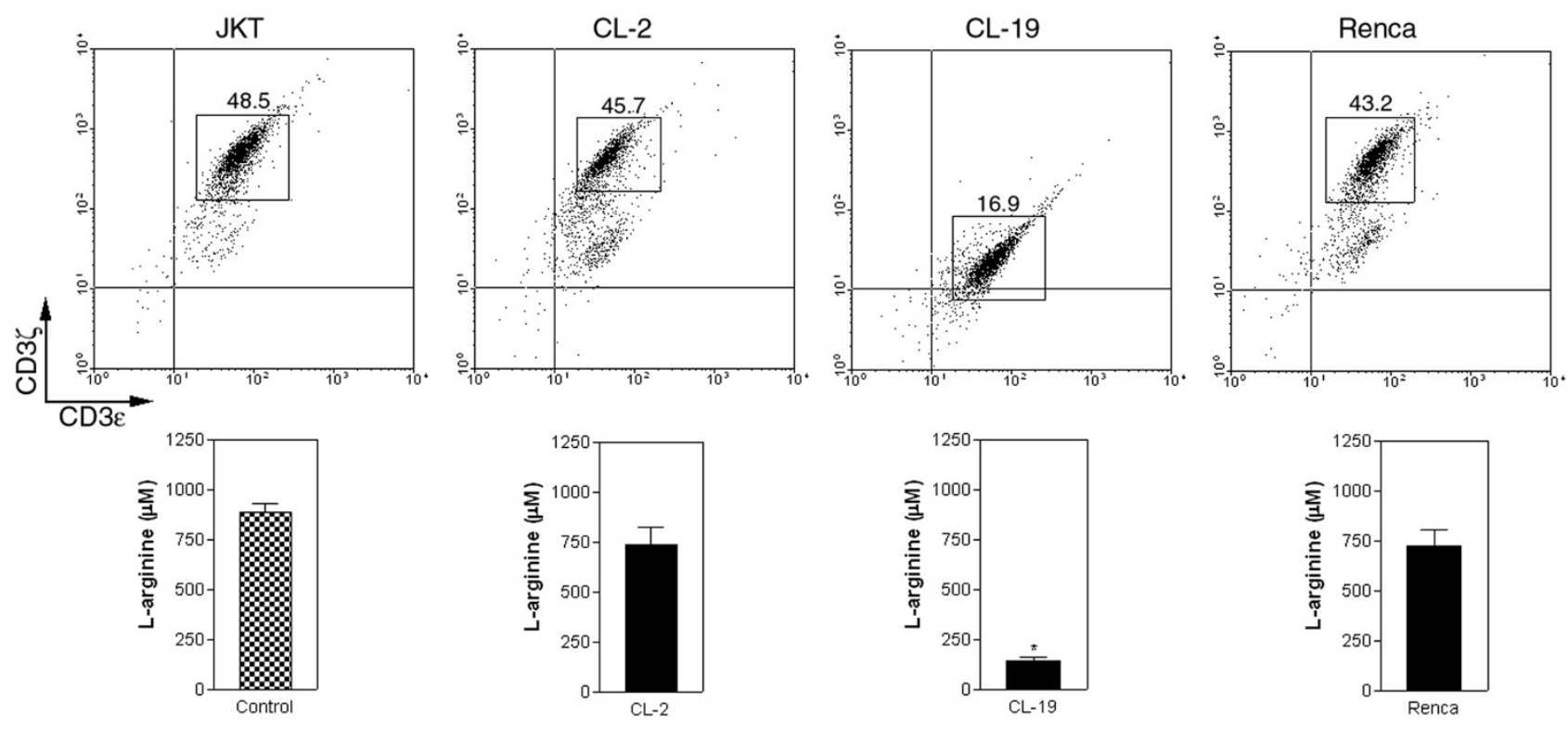

Figure 5

L-arginine deprivation and its effect on CD3 $\zeta$ expression. (Upper panel) Expression of CD3 $\zeta$ in Jurkat T-cells (JKT) cultured for 48 hours alone (control) or co-cultured in trans-wells with CL-2, CL-19, or Renca cell. Differences in CD3 $\zeta$ expression were measured by mean fluorescence intensity. (Lower panel) L-arginine levels in supernatants after 48 hours of coculture of Jurkat cells with the cell lines. Levels of L-arginine were significantly lower $(* P<0.00 \mathrm{I})$ in CL- 19 co-cultures than in Jurkat control or in co-cultures with CL-2 and Renca cell lines. Data shown is representative of a single experiment at 48 hours in culture.

required for tumor cell growth could be a novel approach to control it. The study of the mechanisms by which arginase II activity and L-arginine depletion affect tumor growth will help better understand the biology of RCC and its interaction with the immune system. The results of these studies may provide future therapeutic benefits.

\section{Conclusion}

Arginase II produced by renal cell carcinoma cells can modulate L-arginine levels to regulate both cell growth and $\mathrm{T}$ cell function. Blocking arginase may lead to a decrease in RCC cell growth and aid in restoring immune function by blocking the formation of polyamines, thus providing a novel therapeutic advance.

\section{Competing interests}

The authors declare that they have no competing interests.

\section{Authors' contributions}

DJT participated in the design of the study, developed HPLC for the detection of amino acid levels, performed RT-PCR, analyzed the collected data and wrote the manuscript; DJV participated in the study design and conducted western blots and arginase activity assays; YAC participate in the analysis of HPLC data and design and conducted functional assays; TM participated in tissue culture and preparation of cell lysates and RNA extractions; JRP participated in performing arginase activity assays, western blots, amino acid assays and data collection; DHA was involved in the analysis and interpretation of data and critically revised the manuscript; AHZ designed the study, performed flow cytometry assays, analyzed and interpreted the data and wrote the manuscript. All authors read and approved the manuscript.

\section{Acknowledgements}

The authors greatly thank $\mathrm{Dr}$. Robert $\mathrm{H}$. Wiltrout who kindly provided us with the cell lines, Drs. James Thompson and Ben L. Kelly for the critical review of the manuscript, Dr. Heidi Davis for helping in editing of the manuscript and Claudia Hernandez for her technical assistance.

\section{References}

I. Brittenden J, Heys SD, Ross J, Park KG, Eremin O: Nutritional pharmacology: effects of L-arginine on host defences, response to trauma and tumour growth. Clin Sci (Lond) 1994, 86: $123-132$

2. Albina JE, Caldwell MD, Henry WL Jr, Mills CD: Regulation of macrophage functions by L-arginine. J Exp Med 1989, 169:1021-1029.

3. Ochoa JB, Strange J, Kearney P, Gellin G, Endean E, Fitzpatrick E: Effects of L-arginine on the proliferation of $T$ lymphocyte subpopulations. JPEN J Parenter Enteral Nutr 200I, 25:23-29.

4. Wu G, Morris SM Jr: Arginine metabolism: nitric oxide and beyond. Biochem J 1998, 336(Pt I): I-17.

5. Pegg AE, McCann PP: Polyamine metabolism and function. Am J Physiol 1982, 243:C2 I2-C22I. 
6. Miyanaka K, Gotoh T, Nagasaki A, Takeya M, Ozaki M, Iwase K, Takiguchi M, lyama KI, Tomota K, Mori M: Immunohistochemical localization of arginase II and other enzymes of arginine metabolism in rat kidney and liver. Histochem J 1998, 30:74I-75I.

7. Bernard A, Kasten M, Meier C, Manning E, Freeman S, Adams W, Chang $P$, Boulanger B, Kearney P: Red blood cell arginase suppresses Jurkat ( $T$ cell) proliferation by depleting arginine. Surgery 2008, 143:286-291.

8. Munder M, Mollinedo F, Calafat J, Canchado J, Gil-Lamaignere C, Fuentes JM, Luckner C, Doschko G, Soler G, Eichmann K, Muller FM, Ho $A D$, Goerner $M$, Modolell M: Arginase I is constitutively expressed in human granulocytes and participates in fungicidal activity. Blood 2005, 105:2549-2556.

9. Gotoh T, Araki M, Mori M: Chromosomal localization of the human arginase II gene and tissue distribution of its mRNA. Biochem Biophys Res Commun 1997, 233:487-491.

10. Braissant O, Gotoh T, Loup M, Mori M, Bachmann C: L-arginine uptake, the citrulline-NO cycle and arginase II in the rat brain: an in situ hybridization study. Brain Res Mol Brain Res 1999, 70:23|-24I.

II. Jenkinson CP, Grody WW, Cederbaum SD: Comparative properties of arginases. Comp Biochem Physiol B Biochem Mol Biol 1996, I 14:107-132.

12. Bernard AC, Mistry SK, Morris SM Jr, O'Brien WE, Tsuei BJ, Maley ME, Shirley LA, Kearney PA, Boulanger BR, Ochoa JB: Alterations in arginine metabolic enzymes in trauma. Shock 2001, 15:215-219.

13. Jacob TD, Ochoa JB, Udekwu AO, Wilkinson J, Murray T, Billiar TR, Simmons RL, Marion DW, Peitzman AB: Nitric oxide production is inhibited in trauma patients. I Trauma 1993, 35:590-596.

14. Zea AH, Rodriguez PC, Atkins MB, Hernandez C, Signoretti S, Zabaleta J, McDermott D, Quiceno D, Youmas A, O'Neill A, Mier J, Ochoa AC: Arginase-producing myeloid suppressor cells in renal cell carcinoma patients: a mechanism of tumor evasion. Cancer Res 2005, 65:3044-3048

15. Vockley JG, Jenkinson CP, Shukla H, Kern RM, Grody WW, Cederbaum SD: Cloning and characterization of the human type II arginase gene. Genomics 1996, 38: II8-I23.

16. Singh R, Pervin S, Karimi A, Cederbaum S, Chaudhuri G: Arginase activity in human breast cancer cell lines: $N$ (omega) hydroxy-L-arginine selectively inhibits cell proliferation and induces apoptosis in MDA-MB-468 cells. Cancer Res 2000, 60:3305-33।2

17. Buga GM, Wei LH, Bauer PM, Fukuto JM, Ignarro Ll: NG-hydroxyL-arginine and nitric oxide inhibit Caco-2 tumor cell proliferation by distinct mechanisms. Am J Physiol 1998 275:RI256-RI264.

18. Mumenthaler SM, Yu H, Tze S, Cederbaum SD, Pegg AE, Seligson DB, Grody WW: Expression of arginase II in prostate cancer. Int J Oncol 2008, 32:357-365

19. Rodriguez PC, Zea AH, DeSalvo J, Culotta KS, Zabaleta J, Quiceno DG, Ochoa JB, Ochoa AC: L-arginine consumption by macrophages modulates the expression of CD3 zeta chain in T lymphocytes. J Immunol 2003, I 7 I:I 232-1239.

20. Deignan JL, Livesay JC, Yoo PK, Goodman SI, O'Brien WE, lyer RK, Cederbaum SD, Grody WW: Ornithine deficiency in the arginase double knockout mouse. Mol Genet Metab 2006, 89:87-96.

21. lyer RK, Yoo PK, Kern RM, Rozengurt N, Tsoa R, O'Brien WE, YU $H$, Grody WW, Cederbaum SD: Mouse model for human arginase deficiency. Mol Cell Biol 2002, 22:449|-4498.

22. Gruys ME, Back TC, Subleski J, Wiltrout TA, Lee JK, Schmidt L, Watanabe M, Stanyon R, Ward JM, Wigginton HM, Wiltrout RH: Induction of transplantable mouse renal cell cancers by streptozotocin: in vivo growth, metastases, and angiogenic phenotype. Cancer Res 200I, 61:6255-6263.

23. Zea AH, Curti BD, Longo DL, Alvord WG, Strobl SL, Mizoguchi H, Creekmore SP, O'Shea Jj, Powers GC, Urba WJ, Ochoa AC: Alterations in $\mathbf{T}$ cell receptor and signal transduction molecules in melanoma patients. Clin Cancer Res 1995, I:I327-1335.

24. Zea AH, Culotta KS, Ali J, Mason C, Park HJ, Zabaleta J, Garcia LF, Ochoa AC: Decreased expression of CD3zeta and nuclear transcription factor kappa B in patients with pulmonary tuberculosis: potential mechanisms and reversibility with treatment. J Infect Dis 2006, 194:1385-1393.
25. Zea AH, Rodriguez PC, Culotta KS, Hernandez CP, DeSalvo J, Ochoa JB, Park HJ, Zabaleta J, Ochoa AC: L-Arginine modulates CD3zeta expression and $T$ cell function in activated human T lymphocytes. Cell Immunol 2004, 232:2I-3I.

26. Cederbaum SD, Yu H, Grody WW, Kern RM, Yoo P, lyer RK: Arginases I and II: do their functions overlap? Mol Genet Metab 2004, 8 I (Suppl I):S38-S44.

27. Kepka-Lenhart D, Mistry SK, Wu G, Morris SM Jr: Arginase I: a limiting factor for nitric oxide and polyamine synthesis by activated macrophages? Am J Physiol Regul Integr Comp Physiol 2000, 279:R2237-R2242.

28. Wei LH, Wu G, Morris SM Jr, Ignarro LJ: Elevated arginase expression in rat aortic smooth muscle cells increases cell proliferation. Proc Natl Acad Sci (USA) 200I, 98:9260-9264.

29. Li H, Meininger CJ, Kelly KA, Hawker JR Jr, Morris SM Jr, Wu G Activities of arginase I and II are limiting for endothelial cell proliferation. Am J Physiol Regul Integr Comp Physiol 2002, 282:R64-R69.

30. Munder M, Schneider H, Luckner C, Giese T, Langhans CD, Fuentes JM, Kropf P, Mueller I, Kolb A, Modolell M, Ho AD: Suppression of T-cell functions by human granulocyte arginase. Blood 2006, 108:1627-1634

31. Li H, Meininger Cl, Hawker JR Jr, Haynes TE, Kepka-Lenhart D, Mistry SK, Morris SM Jr, Wu G: Regulatory role of arginase I and II in nitric oxide, polyamine, and proline syntheses in endothelial cells. Am J Physiol Endocrinol Metab 200I, 280:E75-E82.

32. Murphy C, Newsholme P: Importance of glutamine metabolism in murine macrophages and human monocytes to L-arginine biosynthesis and rates of nitrite or urea production. Clin $\mathrm{Sci}$ (Lond) 1998, 95:397-407.

33. Tenu JP, Lepoivre M, Moali C, Brollo M, Mansuy D, Bouche JL: Effects of the new arginase inhibitor $N$ (omega)-hydroxy-nor-Larginine on NO synthase activity in murine macrophages. Nitric Oxide 1999, 3:427-438.

34. Bronte V, Kasic T, Gri G, Gallana K, Borsellino G, Marigo I, Battistini $L$, lafrate M, Prayer-Galetti T, Pagano F, Viola A: Boosting antitumor responses of $\mathrm{T}$ lymphocytes infiltrating human prostate cancers. J Exp Med 2005, 20 I: I 257-1 268.

35. Buga GM, Singh R, Pervin S, Rogers NE, Schmitz DA, Jenkinson CP, Cederbaum SD, Ignarro LJ: Arginase activity in endothelial cells: inhibition by NG-hydroxy-L-arginine during high-output NO production. Am / Physiol 1996, 271: $\mathrm{HI} 988-\mathrm{H} 1998$.

36. Scott L, Lamb J, Smith S, Wheatley DN: Single amino acid (arginine) deprivation: rapid and selective death of cultured transformed and malignant cells. Br J Cancer 2000, 83:800-810.

37. Philip R, Campbell E, Wheatley DN: Arginine deprivation, growth inhibition and tumour cell death: 2 . Enzymatic degradation of arginine in normal and malignant cell cultures. $\mathrm{Br} /$ Cancer 2003, 88:613-623

38. Wheatley DN, Campbell E: Arginine deprivation, growth inhibition and tumour cell death: 3 . Deficient utilization of citrulline by malignant cells. Br J Cancer 2003, 89:573-576.

39. Yoon CY, Shim YJ, Kim EH, Lee JH, Won NH, Kim JH, Park IS, Yoon $\mathrm{DK}, \mathrm{Min} \mathrm{BH}$ : Renal cell carcinoma does not express argininosuccinate synthetase and is highly sensitive to arginine deprivation via arginine deaminase. Int / Cancer 2007, I 20:897-905.

40. Bronte $\mathrm{V}$, Zanovello P: Regulation of immune responses by Larginine metabolism. Nat Rev Immunol 2005, 5:64I-654.

4l. Baniyash M: TCR zeta-chain downregulation: curtailing an excessive inflammatory immune response. Nat Rev Immunol 2004, 4:675-687.

42. Taheri F, Ochoa JB, Faghiri Z, Culotta K, Park HJ, Lan MS, Zea AH, Ochoa AC: L-Arginine regulates the expression of the T-cell receptor zeta chain (CD3zeta) in Jurkat cells. Clin Cancer Res 2001, 7:958s-965s.

43. Selamnia M, Mayeur C, Robert V, Blachier F: $\alpha$-difluoromethylornithine (DFMO) as a potent arginase activity inhibitor in human colon carcinoma cells. Biochemical Pharmacology 1998 , 55: $124 \mid-1245$.

44. Gupta S, Ahmad N, Marengo SR, MacLennan GT, Greenberg NM, Mukhtar $\mathrm{H}$ : Chemoprevention of prostate carcinogenesis by $\alpha$-difluoromethylornithine in TRAMP mice. Cancer Res 2000 , 60:5I25-5I33.

45. Simoneau AR, Gerner EW, Nagle R, Argyrios Ziogas A, FujikawaBrooks S, Hagit Yerushalmi H, Ahlering TE, Lieberman R, Christine E, McLaren CE, Anton-Culver H, Frank L, Meyskens FL Jr: The effect 
of difluoromethylornithine on decreasing prostate size and polyamines in men: results of a year-long phase Ilb randomized placebo-controlled chemoprevention trial. Cancer Epidemiology Markers 2008, 17:292-299.

46. Dutcher JP, Fine JP, Krigel RL, Murphy BA, Schaefer PL, Ernstoff MS, Loehrer PJ: Stratification by risk factors predicts survival on the active treatment arm in a randomized phase II study of interferon-gamma plus/minus interferon-alpha in advanced renal cell carcinoma (E6890). Med Oncol 2003, 20:27I-28I.

Publish with Biomed Central and every scientist can read your work free of charge

"BioMed Central will be the most significant development for disseminating the results of biomedical research in our lifetime."

Sir Paul Nurse, Cancer Research UK

Your research papers will be:

- available free of charge to the entire biomedical community

- peer reviewed and published immediately upon acceptance

- cited in PubMed and archived on PubMed Central

- yours - you keep the copyright 